\title{
Weed Management Strategies for Organic Farming of Kharif Groundnut
}

\author{
RK Mathukia*, MA Shekh, BK Sagarka and RL Davaria \\ Department of Agronomy, College of Agriculture, Junagadh Agricultural University, India
}

Received: December 04, 2017; Published: December 14, 2017

*Corresponding author: RK Mathukia Department of Agronomy, College of Agriculture, Junagadh Agricultural University, India, Tel: 7600455459; Email: mailto:rkmathukia@jau.in

Abstract

A field experiment was conducted during kharif seasons of 2015 and 2016 at Junagadh (Gujarat) to study the weed management in groundnut (Arachis hypogaea L.) under organic farming. The pre-sowing (Deep ploughing, stale seedbed and soil solarization) and post-sowing (Wheat straw mulch @ $5 \mathrm{t} / \mathrm{ha}$, hand weeding \& interculturing at 15, 30 and 45 DAS, Weed-free check and Weedy check) treatments were evaluated. The results revealed that stale seedbed, followed by soil solarisation were found effective in controlling weeds and improving growth and yield attributes and ultimately pod and haulm yield over deep ploughing. Results further indicated that hand weeding \& interculturing at $15,30 \& 45$ DAS and wheat straw mulch @ 5 t/ha significantly suppressed weed growth and enhanced growth and yield of groundnut.

Groundnut is a major crop of Saurashtra region and demand of organically produce groundnut is increasing day by day due to health conscious and premium price of organic product tempted to farmers for organic cultivation. Organic farming is a production system, which avoids or largely excludes the use of synthetically compound to maximum extent feasible. organic farming rely upon crop rotation, crop residues, animal manures, green manures, off farm wastes, mechanical cultivation, mineral bearing rocks and aspect of biological pest control to maintain soil productivity, to supply plant nutrients and to control insects, pathogens and weeds [1].

Weeds are widely reported as a key constraint in organic farming and organic weed management relies on preventive, mechanical, physical, cultural and biological methods, but these tools must be used in an integrated, multi-strand approach. In addition to direct and cultural techniques, timeliness, vigilance and an understanding of farm ecology are also important factors in effective weed management [2].

Generally, in organic farming weeds are managed by integrating various methods, among them, adoption of stale seed bed techniques in which one or two flushes of weeds are destroyed before planting the crop and deep ploughing methods buried the weed seeds in deeper soil layer or destroyed through sun heating to some extent. Sarma and Gautam [3] reported that tillage system and stale seed bed techniques in maize significantly reduce weed density, weed dry weight and increased grain yield. Soil solarisation during summer month desiccate weed seeds present at top soil depth [4]. Study on groundnut showed that soil solarisation suppressed weeds and increase groundnut yield [5] and Sundari and Kumar [6]. Application of organic mulch also found effective for controlling weeds but also add organic matter in soil. Therefore, an experiment is plan to find out most effective and economically viable combination of preventive, mechanical, physical and cultural methods of weed control to manage the weeds in kharif organic groundnut.

\section{Materials and Methods}

The field experiment was conducted on medium black calcareous clayey soil at Organic Farm, Department of Agronomy, College of Agriculture, Junagadh Agricultural University, Junagadh (Gujarat) during kharif seasons of 2015 and 2016 to evaluate non-chemical weed management practices in groundnut. The experimental soil was slightly alkaline in reaction with $\mathrm{pH} 8.0$ and EC $0.61 \mathrm{dS} / \mathrm{m}$. It was medium in available nitrogen (235 kg/ha), low in available phosphorus (23 kg/ha) and high in available potash (385 kg/ha). The experiment comprised pre-sowing treatments (M1: Deep ploughing, M2: Stale seedbed and M3: Soil solarization) as main plots and post-sowing treatments (S1: Wheat straw mulch

@ 5 t/ha, S2: Hand weeding \& interculturing at 15, 30 and 45 DAS, S3: Weed-free check and S4: Weedy check) as sub plots were laid in a split plot design with four replications. The groundnut variety 'Gujarat Groundnut 20' was sown in June at spacing of $60 \mathrm{~cm}$ x 10 cm using seed rate of 120 kg/ha. FYM @ 10 t/ha was incorporated in soil at the time of preparatory tillage. For soil solarization, a light irrigation was applied and then the soil was covered with 25 micron LDPE sheet for 15 days during hot summer (May). Deep ploughing up to $20 \mathrm{~cm}$ depth was carried out using mouldboard plough. For stale seedbed, a pre-sowing irrigation was applied to allow weeds to grow. After 7 days germinated weeds were removed by 
shallow harrowing. The wheat straw mulch @ 5 t/ha was uniformly distributed on the top soil after sowing. The crop was raised as per the standard package of practices without any chemical input.

\section{Results and Discussion}

The major weed flora noticed were Echinochloa colona, Dactyloctenium aegyptium, Eluropus villosus, Indigofera glandulosa and Brachiaria ramosa among the monocots; Ammannia baccifera, Leucas aspera, Digera arvensis, Commelina benghalensis, Eclipta alba, Portulaca oleracea and Phyllanthus niruri among the dicot weeds and Cyperus rotundus as sedge weed.

\section{Effect on Crop}

Data presented in (Table 1) showed that significantly the highest branches/plant, pods/plant and 100-kernel weight were recorded under stale seedbed, followed by soil solarisation. However, plant height and shelling per cent remained unaffected. Whereas, significantly the lowest values of these growth and yield attributes were registered under deep ploughing. Significantly higher values of plant height, branches/plant, pods/plant, 100-kernel weight and shelling per cent were registered with weed-free, followed by HW and straw mulch. The weedy check recorded significantly the lowest values of these growth and yield attributes.

Table 1: Effect of weed management on growth and yield attributes of groundnut (Pooled over two years).

\begin{tabular}{|c|c|c|c|c|c|}
\hline Treatment & Plant height $(\mathrm{cm})$ & Branches/plant & Mature pods/plant & 100-kernel weight (g) & Shelling (\%) \\
\hline \multicolumn{6}{|l|}{ Pre-sowing } \\
\hline Deep ploughing & 41.10 & 4.51 & 8.39 & 42.14 & 63.45 \\
\hline Stale seedbed & 44.43 & 6.75 & 12.17 & 50.40 & 66.94 \\
\hline Soil solarization & 43.95 & 6.01 & 11.52 & 48.81 & 66.46 \\
\hline $\mathrm{CD}(\mathrm{P}=0.05)$ & NS & 0.39 & 0.55 & 1.97 & NS \\
\hline \multicolumn{6}{|l|}{ Post-sowing } \\
\hline Straw mulch & 42.91 & 4.93 & 10.17 & 45.11 & 64.33 \\
\hline HW \& IC & 45.53 & 6.74 & 12.37 & 50.69 & 66.67 \\
\hline Weed free & 46.79 & 7.17 & 12.94 & 53.22 & 70.86 \\
\hline Weedy check & 37.41 & 4.19 & 7.29 & 39.44 & 60.61 \\
\hline $\mathrm{CD}(\mathrm{P}=0.05)$ & 1.85 & 0.41 & 0.52 & 1.86 & 3.09 \\
\hline
\end{tabular}

Table 2: Effect of weed management on crop yield and weed parameters (Pooled over two years).

\begin{tabular}{|c|c|c|c|c|c|}
\hline Treatment & Pod yield (kg/ha) & Haulm yield (kg/ha) & $\begin{array}{l}\text { Weed dry weight } \\
(\mathrm{kg} / \mathrm{ha})\end{array}$ & Weed index(\%) & $\begin{array}{l}\text { Weed control } \\
\text { efficiency }(\%)\end{array}$ \\
\hline \multicolumn{6}{|l|}{ Pre-sowing } \\
\hline Deep ploughing & 907 & 1972 & 921 & 21.44 & 47.63 \\
\hline Stale seedbed & 1118 & 2498 & 634 & 19.47 & 53.91 \\
\hline Soil solarization & 1086 & 2454 & 764 & 21.57 & 50.44 \\
\hline $\mathrm{CD}(\mathrm{P}=0.05)$ & 68 & 179 & 43 & & \\
\hline \multicolumn{6}{|l|}{ Post-sowing } \\
\hline Straw mulch & 1013 & 2271 & 1049 & 22.67 & 32.93 \\
\hline HW \& IC & 1221 & 2655 & 441 & 6.75 & 72.32 \\
\hline Weed free & 1309 & 2826 & 43 & 0.00 & 97.39 \\
\hline Weedy check & 606 & 1480 & 1558 & 53.87 & 0.00 \\
\hline $\mathrm{CD}(\mathrm{P}=0.05)$ & 59 & 139 & 53 & & \\
\hline
\end{tabular}

The results (Table 2) revealed that stale seedbed produced significantly the highest pod and haulm yields, followed by soil solarisation. The deep ploughing resulted in significantly the lowest pod and haulm yields. The weed-free check produced significantly the highest pod yield of $1309 \mathrm{~kg} / \mathrm{ha}$ and haulm yield of $2826 \mathrm{~kg} / \mathrm{ha}$. The next best treatments in this regard were HW and straw mulch. Efficient control of weeds under these treatments might have allowed competition-free environment to the crop, which improved growth and yield attributes and ultimately reflected in yield. These results are in conformity with findings of Ghosh et al. [7]. and Arora and Tomar [8].

\section{Effect on weeds}

The data (Table 2) indicated that the stale seedbed recorded significantly the lowest dry weight of weeds, followed by soil solarisation and deep ploughing having WI of 19.47, 21.57 and $21.44 \%$, and WCE of 53.91, 50.44 and $47.63 \%$, respectively. Similarly, the weed-free registered significantly the lowest dry weight of weeds, followed by HW and straw mulch with WI of 0.00 , 6.75 and $22.67 \%$ and WCE of $97.39,72.32$ and $32.93 \%$, respectively. Effective control of weeds starting from sowing of the crop under the above mentioned treatments might have resulted in less dry 
weight of weeds and eventually exhibited excellent weed indices. The results corroborate the findings of Johnson and Mullinix [9] and Ramakrishna et al. [10].

\section{Conclusion}

Effective control of weeds in kharif groundnut along with higher yield under organic farming could be achieved by stale seedbed and either hand weeding at 15, 30 \& 45 DAS or wheat straw mulch @ $5 \mathrm{t} / \mathrm{ha}$.

\section{References}

1. Sharma AK (2002) A Hand Book of Organic Farming. Agrobios Pub Jodhpur, India.

2. Marshall $\mathrm{T}$ (1992) Weed control in organic farming systems. In proceedings of the First International Weed Control Congress pp. 311314.

3. Sarma CK and Gautam RC (2006) Effect of tillage, seed rate and weed control methods on weeds and maize (Zea mays L). Indian J Weed Sci 36(1\&2): 58-61.
4. Kumar B, Yaduraju NT, Ahuja KN and Prasad D (1993) Effect of soil solarization on weeds and nematodes under tropical Indian conditions. Weed Research 33: 423-429.

5. Anon (2004) A Research Report of $40^{\text {th }}$ meeting of the Agronomy and Soil Science Sub-committee of the Agricultural Research Council, Department of Agronomy, JAU, Junagadh, pp. 26-27.

6. Sundari A and Kumar SM (2008) Effect of soil solarization on the weed control, weed seed dynamics and pod yield of groundnut (Arachis hypogaea L) Indian J Agric Res 42(2): 150-152.

7. Ghosh PK, Devi Dayal, Bandyopadhyay KK and Mohanty M (2006) Evaluation of straw and polythene mulch for enhancing productivity of irrigated summer groundnut. Field Crops Research 99(6): 76-86.

8. Arora A and Tomar SS (2012) Effect of soil solarization on weed seed bank in soil. Indian Journal of Weed Science 44(2): 122-123.

9. Johnson WC and Mullinix BG (1995) Weed management in peanut using stale seedbed techniques. Weed Science 43(2): 293-297.

10. Ramakrishna A, Tam HM, Wani SP and Long TD (2006) Effect of mulch on soil temperature, moisture, weed infestation and yield of groundnut in northern Vietnam. Field Crops Research 95(2-3): 115-125.

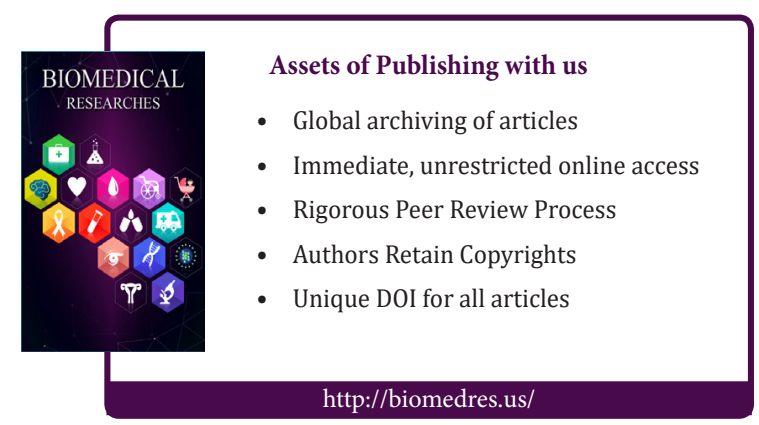

